\title{
Ecology of endoparasites of the fluvial stingray Potamotrygon falkneri (Chondrichthyes: Potamotrygonidae) from the upper Paraná River floodplain, Brazil
}

\author{
Lacerda, ACF.*, Takemoto, RM. and Pavanelli, GC. \\ Programa de Pós-graduação em Ecologia de Ambientes Aquáticos Continentais, \\ Núcleo de Pesquisas em Limnologia, Ictiologia e Aquicultura - Nupélia, \\ Departamento de Biologia, Universidade Estadual de Maringá - UEM, \\ Av. Colombo, 5790, bloco G90, sala 11, CEP 87020-900, Maringá, PR, Brazil \\ *e-mail: ana-carol-lacerda@ hotmail.com
}

Received October 22, 2007 - Accepted January 30, 2008 - Distributed May 31, 2009

(With 3 figures)

\begin{abstract}
The present study investigated the ecological relationships between endoparasites and the host Potamotrygon falkneri from the upper Paraná River by using as indicators the host's relative condition factor $(\mathrm{Kn})$, sex and hepatosomatic relation (HSR). Forty-seven specimens of P. falkneri were analyzed between March 2005 and September 2006. Statistical analysis showed that the Kn was positively correlated with the abundance of Acanthobothrium regoi and Rhinebothrium paratrygoni; only the abundance of A. regoi was positively correlated to the HSR, whereas R. paratrygoni did not present correlation and there was no influence of the host's sex on the abundance and prevalence of parasites. This is the first study concerning the ecology of parasites of potamotrygonids.
\end{abstract}

Keywords: potamotrygonids, parasites, relative condition factor, hepatosomatic relation, Paraná.

\section{Ecologia de endoparasitos da raia fluvial Potamotrygon falkneri (Chondrichthyes: Potamotrygonidae) da planície de inundação do alto rio Paraná, Brasil}

\section{Resumo}

O presente estudo investigou as relações ecológicas entre os endoparasitos e os hospedeiros Potamotrygon falkneri do alto rio Paraná, utilizando como indicadores o fator de condição relativo $(\mathrm{Kn})$, sexo e relação hepatossomática (HSR) dos hospedeiros. Entre março de 2005 e setembro de 2006, 47 espécimes de P. falkneri foram analisados. As análises mostraram que o Kn estava positivamente correlacionado com a abundância de Acanthobothrium regoi e Rhinebothrium paratrygoni; apenas a abundância de A. regoi estava correlacionada positivamente com a HSR, enquanto $R$. paratrygoni não apresentou correlação e não houve influência do sexo do hospedeiro na abundância e prevalência dos parasitos. Este é o primeiro estudo sobre ecologia de parasitos de potamotrigonídeos.

Palavras-chave: potamotrigonídeos, parasitos, fator de condição relativo, relação hepatossomática, Paraná.

\section{Introduction}

Potamotrygon falkneri Castex (Potamotrygonidae) is a fluvial stingray found in the Paraná-Paraguay basin, from the Cuiabá River to La Plata River (Carvalho et al., 2003). Despite of some studies on the systematic (Rego, 1979; Marques and Brooks, 2003) and phylogeny (Brooks, 1992) of endoparasites of potamotrygonids, little is known about this host-parasite association. The application of indicators that use organs as the liver and the relative condition factor of fishes regarding the levels of parasitism are important tools for understanding the ecological relationship between parasites and hosts (Lizama et al., 2006). Thus, the present study had the objective to analyze $P$. falkneri and its endoparasites from the upper Paraná River floodplain, using the sex, the relative condition factor and the hepatosomatic relation of the hosts.

\section{Materials and Methods}

Forty-seven specimens of P. falkneri were analyzed, captured between March 2005 and September 2006 in the upper Paraná River floodplain, near the City of Porto Rico, Paraná and Mato Grosso do Sul States (22 $43^{\circ} \mathrm{S}$ and $53^{\circ} 10^{\prime} \mathrm{W}$ ) (Figure 1). 


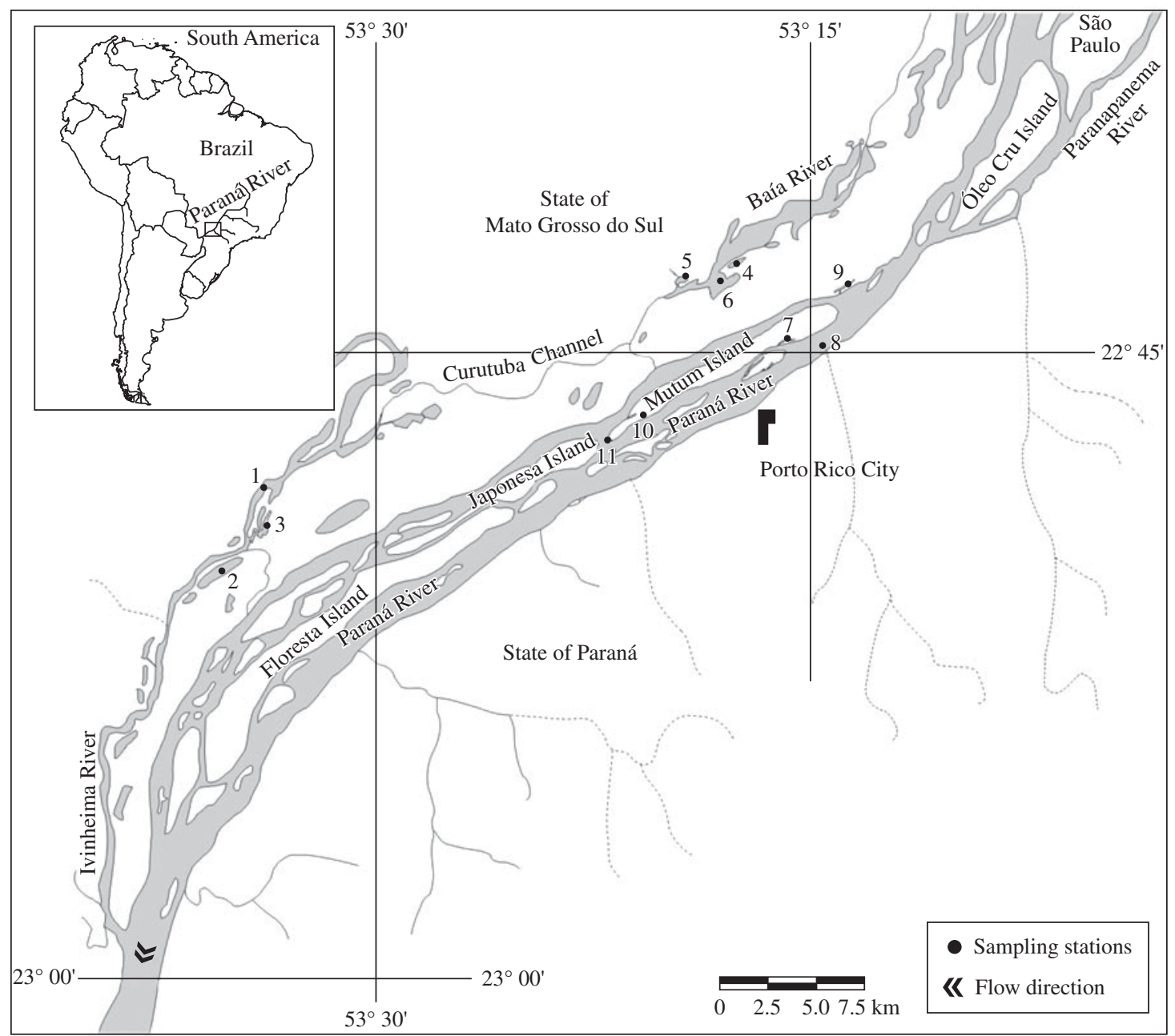

Figure 1. Upper Paraná River floodplain. Sampling stations: 1 - Ivinhema River; 2 - Ventura Lagoon; 3 - Patos Lagoon; 4 - Fechada Lagoon; 5 - Guaraná Lagoon; 6 - Baía River; 7 - Pau Véio backwater; 8 - Paraná River; 9 - Garças Lagoon; 10 - Osmar Lagoon; and 11 - Mutum Island.

Total length, disk length, total weight, liver weight and sex of the captured fish were recorded. Sampling, fixation, conservation and preparation of the endoparasites followed the methodology of Eiras et al. (2006).

Diversity was calculated by the Brillouin index (HB). To verify the existence of dominant taxa in the infracommunities, the index of dominance of Simpson was calculated. The dispersion patterns of the parasite species were determined by the index of dispersion (ID) and tested by the statistic $d$. The Green index (GI) was used for measuring the aggregation level of the species. The values of importance of the taxa in the infracommunities of endoparasites were determined according to the value of importance of Caswell (1978) and Hanski (1982), cited by Bush and Holmes (1986).

The influence of the sex of the hosts on the abundance and prevalence of each species of parasite was determined by the Mann-Whitney $U$ test and by statistic
$G$ ("log-likelihood"), respectively. The relative condition factor $(\mathrm{Kn})$ was calculated, considering the coefficient between the observed weight and the weight theoretically expected for a given length (Le Cren, 1951). The hepatosomatic relation (HSR\%) was calculated by the expression: liver weight (g)/body weight $(\mathrm{g})$ x 100. For each species of parasite, the Spearman rank correlation "rs" was calculated between abundance and $\mathrm{Kn}$ and abundance and HSR. The tests adopted level of significance of $p \leq 0.05$ and were applied only to the species that presented prevalence higher than $10 \%$. The ecological terminology was based on Rózsa et al. (2000).

\section{Results}

Twenty-two out of 47 specimens of $P$. falkneri presented at least one species of endoparasite (46.8\%). In total, 175 specimens of parasites were collected from the 
intestinal tract of the fish and the group that presented the greatest number of species was Cestoda; Rhinebothrium paratrygoni Rego and Dias presented the highest prevalence and mean abundance (Table 1).

In March 2005, the only fish examined was not parasitized. In April 2005, of 13 specimens of P. falkneri collected, four were parasitized by Rhinebothrium paratrygoni $(30.8 \%)$. In June 2005, eight out of 13 analyzed fish were parasitized $(61.5 \%)$ by the following species: Genarchella sp. (15.4\%), Tylodelphis sp. (metacercariae) (7.7\%), Acanthobothrium regoi Brooks, Mayes and Thorson (15.4\%), R. paratrygoni (53.8\%), Paroncomegas araya (Woodland) (15.4\%), Cestoda (larva) (7.7\%), Brevimulticaecum sp. (larvae) (7.7\%), Cucullanus (Cucullanus) sp. (7.7\%), Echinocephalus sp. (7.7\%), Spinitectus sp. (7.7\%) and Quadrigyrus machadoi Fabio (15.4\%). In September 2005, the only examined fish was parasitized by Genarchella sp., P. araya and $R$. paratrygoni. In December 2005, four analyzed fish were not parasitized, as well as two fish analyzed in March 2006. In May 2006, four out of nine fish were parasitized (44.4\%) by A. regoi (22.2\%) and $R$. paratrygoni $(33.3 \%)$. In June 2006 , the only analyzed specimen was parasitized by $A$. regoi, $P$. araya, Potamotrygonocestus travassosi Rego, $R$. paratrygoni and Clinostomum complanatum (Rudolphi) (metacercaria). In September 2006, one of three analyzed fish was parasitized (33.3\%) by $A$. regoi and $R$. paratrygoni (Figure 2 ).
The species richness of the infracommunities varied from one to five, being constituted by only one species of parasite in the majority of the hosts (Figure 3 ). The community of endoparasites presented mean diversity of $\mathrm{HB}=0.32 \pm 0.35$, with the majority of the hosts under 0.5 . The parasites that presented prevalence higher than $10 \%$, A. regoi and $R$. paratrygoni, presented aggregated distribution (ID $=12.71 ; d=24.67 ; \mathrm{GI}=0.38$ and $\mathrm{ID}=13.25 ; d=25.38$; GI $=0.14$, respectively). No species of parasite was considered central. $R$. paratrygoni was considered secondary and all the other species were considered satellites. There was not dominance in the proportion of parasitized fish regarding the species of parasites $(\mathrm{C}=0.22)$.

The total length of the fish varied between 39.00 and $89.80 \mathrm{~cm}(55.80 \pm 13.80)$. Total weight varied from 375.00 to $7300.00 \mathrm{~g}(1771.90 \pm 1534.60)$. Kn varied between 0.72 and $1.44(1.01 \pm 0.19)$ and the HSR from 0.99 to $6.67(3.23 \pm 1.33)$. The $\mathrm{Kn}$ was positively correlated to the abundance of $A$. regoi $(\mathrm{rs}=0.29 ; \mathrm{p}=0.04)$ and $R$. paratrygoni ( $\mathrm{rs}=0.29 ; \mathrm{p}=0.04$ ). Only the abundance of $A$. regoi was positively correlated to the HSR of the hosts ( $\mathrm{rs}=0.34 ; \mathrm{p}=0.04)$, while $R$. paratrygoni $\mathrm{did}$ not present correlation ( $\mathrm{rs}=0.15 ; \mathrm{p}>0.05$ ).

Twenty-five hosts were females and 22 were males. Significant influences of the host sex on the abundance and prevalence of $A$. regoi $(\mathrm{Z}=0.08$;

Table 1. Parasite taxa, infection sites and parasitism indexes in 47 specimens of Potamotrygon falkneri collected in the upper Paraná River floodplain between March 2005 and September 2006. PF = parasitized fish; $\mathrm{P}=$ prevalence; $\mathrm{MI}=$ mean intensity $\pm \mathrm{SD}$; MOI $=$ mode of intensity; MA $=$ mean abundance $\pm \mathrm{SD}$.

\begin{tabular}{|c|c|c|c|c|c|c|}
\hline \multirow[t]{2}{*}{ Parasite taxa } & \multirow[t]{2}{*}{ Infection sites } & \multicolumn{5}{|c|}{ Parasitism indexes } \\
\hline & & PF & $\mathbf{P}(\%)$ & MI & MOI & MA \\
\hline \multicolumn{7}{|l|}{ Digenea } \\
\hline $\begin{array}{l}\text { Clinostomum complanatum } \\
\text { (Rudolphi, 1819) (metacercaria) }\end{array}$ & Spiral valvae & 1 & 2.13 & 1 & 1 & 0.02 \\
\hline Tylodelphis sp. (metacercariae) & Spiral valvae & 1 & 2.13 & 8 & 8 & 0.17 \\
\hline Genarchella sp. & Stomach & 2 & 4.25 & 1 & 1 & 0.04 \\
\hline \multicolumn{7}{|l|}{ Cestoda } \\
\hline $\begin{array}{l}\text { Acanthobothrium regoi } \\
\text { Brooks, Mayes and Thorson, } 1981\end{array}$ & Spiral valvae & 6 & 12.76 & $5.83 \pm 6.88$ & 1 & $0.74 \pm 3.00$ \\
\hline Paroncomegas araya (Woodland, 1934) & Spiral valvae & 3 & 6.38 & $3 \pm 2.00$ & $1 ; 3 ; 5$ & $0.19 \pm 1.04$ \\
\hline $\begin{array}{l}\text { Potamotrygonocestus travassosi } \\
\text { Rego, } 1979\end{array}$ & Spiral valvae & 1 & 2.13 & 4 & 4 & 0.58 \\
\hline $\begin{array}{l}\text { Rhinebothrium paratrygoni } \\
\text { Rego and Dias, } 1976\end{array}$ & Spiral valvae & 17 & 36.17 & $5 \pm 7.29$ & 1 & $2 \pm 4.98$ \\
\hline \multicolumn{7}{|l|}{ Nematoda } \\
\hline Brevimulticaecum sp. (larvae) & $\begin{array}{l}\text { Stomach } \\
\text { (external wall) }\end{array}$ & 1 & 2.13 & 16 & 16 & 0.34 \\
\hline Cucullanus (Cucullanus) sp. & Spiral valvae & 1 & 2.13 & 3 & 3 & 0.06 \\
\hline Echinocephalus sp. & Spiral valvae & 2 & 2.13 & 1 & 1 & 0.02 \\
\hline Spinitectus sp. & Spiral valvae & 1 & 2.13 & 3 & 3 & 0.06 \\
\hline \multicolumn{7}{|l|}{ Acanthocephala } \\
\hline Quadrigyrus machadoi Fabio, 1983 & Spiral valvae & 3 & 6.38 & $2 \pm 1$ & $1 ; 2 ; 3$ & $0.13 \pm 0.54$ \\
\hline
\end{tabular}




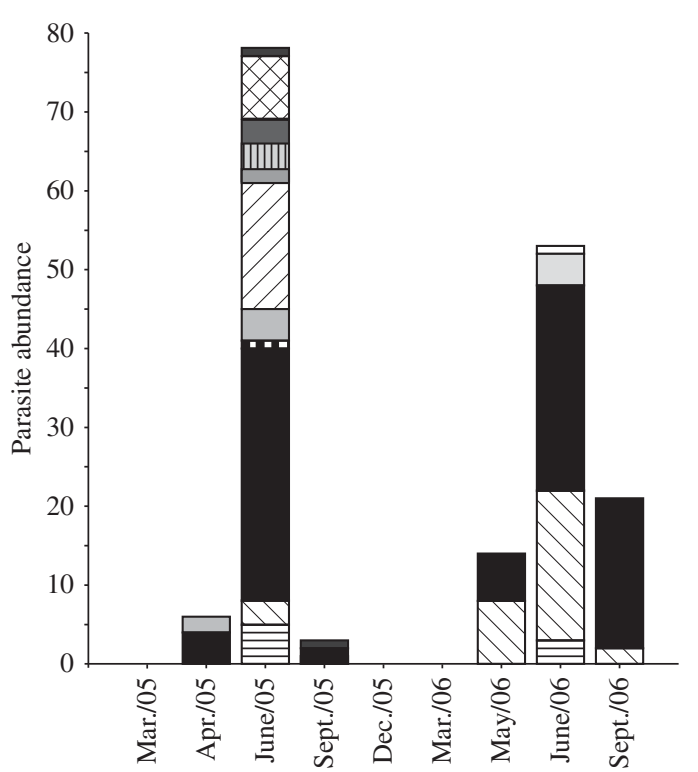

Sampling months

\begin{tabular}{|ll|}
\hline C. complanatum (metacercaria) & $\square$ Q. machadoi \\
Genarchella sp. & $\square$ Cestoda (larva) \\
$\square$ Tylodelphis sp. (metacercariae) & $\square$ P. travassosi \\
$\square$ Cucullanus (Cucullanus) sp. & R. paratrygoni \\
Sininitectus sp. & $\square$ A. regoi \\
$\square$ Echinocephalus sp. & $\square$ P. araya \\
\hline Brevimulticaecum sp. (larvae) & \\
\hline \hline
\end{tabular}

Figure 2. Abundance of parasites of Potamotrygon falkneri in different months in the upper Paraná River floodplain, between March 2005 and September 2006.

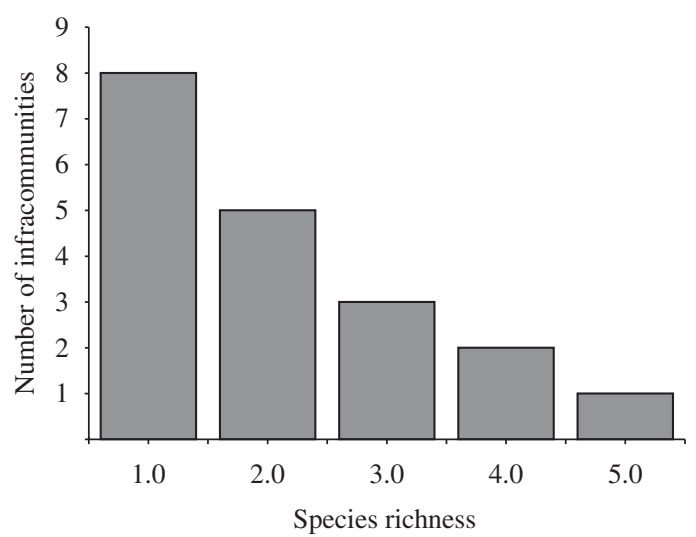

Figure 3. Species richness of parasites in the infracommunities of Potamotrygon falkneri collected in the upper Paraná River floodplain, between March 2005 and September 2006.

$\mathrm{p}>0.05$ and $\mathrm{G}=0.09 ; \mathrm{p}>0.05)$ and $R$. paratrygoni $(\mathrm{Z}=0.11 ; \mathrm{p}>0.05$ and $\mathrm{G}=0.09 ; \mathrm{p}>0.05)$ were not observed. However, P. araya, P. travassosi, Cestoda (larva), Q. machadoi, Brevimulticaecum sp. (larvae),
Echinocephalus sp., Spinitectus sp., Cucullanus sp., Tylodelphis sp. (metacercariae), Genarchella sp. and Clinostomum complanatum (metacercaria) occurred only in females.

\section{Discussion}

Considering all species of parasites, approximately half of the analyzed fish were parasitized (46.8\%). Only one metacercaria of Clinostomum complanatum was found in a single host. It is possible to consider that the host Potamotrygon falkneri acted as an accidental host for this metacercaria, since its prevalence was very low and it is an abundant species in the study region (Pavanelli et al., 2004). The same can be considered for Tylodelphis sp., Brevimulticaecum sp., Cucullanus (Cucullanus) sp. and Spinitectus sp., that were found in only one host, but with higher intensity.

The most prevalent species were Acanthobothrium regoi (12.76\%) and Rhinebothrium paratrygoni (36.17\%), cestodes that are not very specific, but parasitize only potamotrygonids (Brooks and Amato, 1992; Lacerda et al., 2008). Unfortunately, the majority of the studies with parasites of fluvial stingrays do not present information about parasitism levels, but we can say that the prevalence of Acanthobothrium regoi in P. falkneri in the present study is low when compared to other species of Acanthobothrium and other species of hosts, being closer to the values found in Argentina (Ivanov, 2005). Those values indicate that the genus is better represented (in relation to infected hosts) in the populations of marine stingrays. In fact, these parasites are more adapted to the marine environment, since they probably occupied the freshwater environment with the ancestor of the potamotrygonids, during Plioceno (three to five millions years ago) (Brooks, 1992).

Although the number of hosts did not permit a seasonal analyses, a higher number of parasites was observed in May 2005 and May and June 2006. The annual cycles and reproductive periods of fish parasites are frequently related to the hydrologic variation of the habitat of the host, as well as to the fluctuations in the abundance of plankton and bentic organisms (Ginetsinskaya, 1970) and fish that feed on them. Analysing the annual variation of the hydrologic level (monthly mean) of the region, Souza Filho et al. (2004) emphasized a decrease in May and June, being the lowest level recorded in August. According to Machado et al. (1994), intermediate hosts present a tendency to aggregate in the low water period, when the activity of feeding of the fish is more intense. In addition, Lonardoni et al. (2007) analysed the feeding habits of Potamotrygon falkneri in the upper Paraná River floodplain, where they consumed predominantly molluscs in the period of flood and mainly fishes in the dry period. Thus, the high values of prevalence of cestodes observed in June 2005 and May and June 2006 can be explained by the low hydrologic level and consequent increase of the aggregation of intermediate hosts (fish) and of the feeding activity of the stingrays. These re- 
sults contrast with Machado et al. (1994) for the hosts Pseudoplatystoma corruscans and Schizodon borelli, where the highest occurrence of three species of proteocephalideans occurred in the period of high water in the same studied region. The increase of the aggregation of intermediate hosts and of the feeding activity when the climate is dry can also explain the highest species richness recorded in June 2005 and 2006.

According to Poulin (1998), one of the factors that can increase the aggregation of parasites is the reproduction inside the host. When the parasites do not present monoxenic reproduction, the aggregation can be explained by the heterogeneity in the exposition of the individuals to the parasites and in the susceptibility of the individuals to the infections. Considering that the cestodes are not capable of reproducing directly inside the host, the aggregated distribution of A. regoi and $R$. paratrygoni in the analyzed individuals of $P$. falkneri suggests that the population of hosts occupies a great variety of environments in the studied region. Besides, the hosts should also exhibit different levels of tolerance to the infection by parasites, due to genetic or environmental factors (food, stress).

Caswell (1978), cited by Bush and Holmes (1986), proposed the idea that a community is formed by a nucleus of dominant species in equilibrium, enclosured by species interacting against this equilibrium. Hanski (1982), cited by Bush and Holmes (1986), then, elaborated the concept of central species (few frequent and numerous species) and satellites (many species limited in number and low frequency). According to Bush and Holmes (1986), only the central species (in equilibrium) present foreseeable patterns, while satellite species behave in an unstable way. As expected, the majority of the species of parasites were considered satellites. However, the absence of species considered central indicates the absence of this equilibrium proposed by Caswell (1978), cited by Bush and Holmes (1986) and consequently the unpredictability of patterns in the infracommunities of parasites of $P$. falkneri in the studied region. The absence of dominance between the species of parasites was also confirmed by the index of dominance of Simpson, a result that according to Poulin (1998) suggests low, or the absence of, competition inside the infracommunities.

Considering that the parasites are harmful to their hosts, a negative correlation is expected between abundance and $\mathrm{Kn}$. However, in the present study, positive correlation occurred. Studies about the condition factor (K) of parasitized fish show that the parasitism can be related to low values of K or Kn (Tavares-Dias et al., 2000) or increase with the host's condition factor (Lizama et al., 2006), as well as the absence of correlation (RanzaniPaiva et al., 2005). The positive correlations between the relative condition factor of $P$. falkneri and the abundances of $A$. regoi and $R$. paratrygoni indicate that the number of parasite specimens increases along with the condition factor of the fish. As these parasites are transmitted by the feeding activity, these results can be explained by a cumulative process, where stingrays that are in better physical conditions fed on a great quantity of potential intermediate hosts (fish), being more susceptible to infections (Luque et al., 1996).

The present study did not find significant differences between the host's sex regarding parasitism, as mentioned by other authors studying teleosts (Machado et al., 1994). Other authors found differences in the abundance of parasites between males and females, some finding males more parasitized (Takemoto and Pavanelli, 2000), others finding females more parasitized (Lizama et al., 2005).

The composition of the parasite fauna is a product of interactions of biotic and abiotic factors of the environment (Dogiel, 1970). Still according to the same author, the parasite fauna is affected more seriously by the physiological characteristics of the hosts, food being the most important factor. Lonardoni et al. (2007) pointed to molluscs, crustaceans, small fish and aquatic insects as part of the diet of P. falkneri in the upper Paraná River basin, not differing males from females. Despite the absence of significant differences between males and females in the present study, some species of parasites were recorded only in females. The difference between males and females regarding the species of parasites found can be an indicator of feeding and/or behavioural differences between the sexes, or still a result of the cumulative process previously mentioned, since females of P. falkneri exhibit bigger measures than males (Silva, 2006).

According to Aime and Pappas (1983) the effects of parasitism can be observed in organs with which the cestodes do not have contact; fibrosis was observed in the intrahepatic ducts and also lesions on the liver surface of vertebrate hosts.

In teleosts, parasitism can be related with the reduction of the hepatosomatic relation (Kurovskaya and Osadchaya, 1993), to hepatomegaly (Tierney et al., 1996) or do not present liver alterations (Lizama et al., 2006). According to Griffith et al. (1973), correlation exists between the hepatosomatic index and the health of the potamotrygonids; fish with low indexes present very low values of glucose, total carbohydrates, cholesterol, urea and proteins. Thus, the present study indicates that the parasitism by A. regoi can be related to damage to the host's health. $R$. paratrygoni did not present correlation with the hepatosomatic index of the hosts. According to Aime and Pappas (1983), many authors affirm that adult cestodes have little or no harmful effect on the host. That can be due to the long evolutive relation between hosts and parasites and/or to the compensatory effects of alternative physiological mechanisms that can occur in parasitized animals.

Considering that $A$. regoi presented positive correlation with the condition factor and with the HSR of the hosts, doubts arise about which is the best indicator of the real condition of the fish. Future studies are necessary for the determination of the most efficient indicator 
for the evaluation of the damage caused by the relationship parasite-host in potamotrygonids.

Acknowledgements - We would like to thank Nupelia for the logistic support, $\mathrm{CNPq}$ for the financial support and the team field PELD/2005/2006. ACF Lacerda was supported by CAPES (Master's Scholarship) and RM Takemoto and GC Pavanelli were supported by CNPq (Productivity Grant).

\section{References}

AIME, C. and PAPPAS, PW. (Eds.), 1983. Biology of Eucestoda. London: Academic Press Inc. p. 27-80.

BROOKS, DR. and AMATO, FR., 1992. Cestodes Parasites in Potamotrygon motoro (Natterer) (Chondrichthyes: Potamotrygonidae) from Southwestern Brazil, including Rhinebothroides mclennanae $\mathrm{n}$. $\mathrm{sp}$. (Tetraphyllidea: Phyllobothriidae), and a revised host-parasite checklist for helminths inhabiting neotropical freshwater stingrays. Journal of Parasitology, vol. 78, no. 3, p. 393-398.

BROOKS, DR., 1992. Origins, diversification, and historical structure of the helminth fauna inhabiting neotropical freshwater stingrays (Potamotrygonidae). Journal of Parasitology, vol. 78, no. 4 , p. 588-595.

BUSH, AO and HOLMES, JC. 1986. Intestinal helminthes of lesses scaup ducks: patterns of association. Canadian Journal of Zoology, vol. 64, no. 1, p. 132-141.

CARVALHO, MR., LOVEJOY, NR. and ROSA, RS., 2003. Family Potamotrygonidae (River stingrays). In REIS, RE., KULLANDER, SO. and FERRARI, JR. (Orgs.). Check list of fishes of South and Central America. Porto Alegre: EDIPUCRS. p. 22-28.

DOGIEL, VA., 1970. Ecology of the parasites of freshwater fishes. In DOGIEL, VA., PETRUSHEVSKI, GK. and POLYANSKI, Y. (Eds.). Parasitology of fishes. London: Oliver \& Boyd. p. 1-47.

EIRAS, JC., TAKEMOTO, RM. and PAVANELLI, GC., 2006. Métodos de estudio y técnicas laboratoriales en parasitología de peces. 2 ed. Espanha: Editorial Acribia. 133p.

GINETSINSKAYA, TA., 1970. The life cycles of fish helminths and the biology of their larval stages. In DOGIEL, VA., PETRUSHEVSKI, GK. and POLYANSKI, Y. (Eds.). Parasitology of fishes. London: Oliver \& Boyd. p. 140-179.

GRIFFITH, RW., PANG, PKT., SRIVASTAVA, AK. and PICKFORD, GE., 1973. Serum composition of freshwater stingrays (Potamotrygonidae) adapted to fresh and dilute sea water. The Biological Bulletin, vol. 144, p. 304-320.

IVANOV, VA., 2005. A new species of Acanthobothrium (Cestoda: Tetraphyllidea: Onchobothriidae) from the ocellate river stingray, Potamotrygon motoro (Chondrichthyes: Potamotrygonidae), in Argentina Journal of Parasitology, vol. 91, no. 2, p. 390-396.

KUROVSKAYA, LN. and OSADCHAYA, SA., 1993. The influence of Ichthyophirius multifiliis on underyearling carp Cyprinus carpio. Journal of Ichthyology, vol. 33, no. 4, p. $81-92$

LACERDA, ACF, TAKEMOTO, RM and PAVANELLI, GC. 2008. Digenea, Nematoda, Cestoda and Acanthocephala, parasites in Potamotrygonidae (Chondrichthyes) from the upper
Paraná River floodplain, states of Paraná and Mato Grosso do Sul, Brazil. Check List (UNESP), vol. 4, no. 2, p. 115-122.

LE CREN, ED., 1951. The length-weight relationship and seasonal cycle in gonad weight and condition of perch Perca fluviatilis. Journal of Animal Ecology, vol. 20, no. 2, p. 201-219.

LIZAMA, M. de los A., TAKEMOTO, RM. and PAVANELLI, GC., 2005. Influence of host sex and age on infracommunities of metazoan parasites of Prochilodus lineatus (Valenciennes, 1836) (Prochilodontidae) of the Upper Paraná River floodplain, Brazil. Parasite, vol. 12, no. 4, p. 299-304.

,2006. Parasitism influence on the hepato, splenosomatic and weight/length relation and relative condition factor of Prochilodus lineatus (Valenciennes, 1836) (Prochilodontidae) of the Upper Paraná River floodplain, Brazil. Revista Brasileira de Parasitologia Veterinária, vol. 15, no. 3, p. 116-122.

LONARDONI, AP., OLIVEIRA, EF., ABELHA, MCF. and GOULART, E., 2007. Hábitos alimentares e sobreposição trófica das raias Potamotrygon falkneri e Potamotrygon motoro (Chondrichthyes; Potamotrygonidae) na planície alagável do alto rio Paraná; Brasil. In Resumos do XVII Encontro Brasileiro de Ictiologia, 2007. p. 326.

LUQUE, JL., AMATO, JFR. and TAKEMOTO, RM., 1996. Comparative analyses of the communities of metazoan parasites of Orthopristis ruber and Haemulon steindachneri (Osteichthyes: Haemulidae) from the Southeastern Brazilian littoral: I. Structure and influence of the size and sex of hots. Revista Brasileira de Biologia = Brazilian Journal of Biology, vol. 56, no. 2, p. 279-292.

MACHADO, MH., PAVANELLI, GC. and TAKEMOTO, RM., 1994. Influence of host's sex and size on endoparasitic infrapopulations of Pseudoplatystoma corruscans and Schizodon borelli (Osteichthyes) of the high Paraná river, Brazil. Revista Brasileira de Parasitologia Veterinária, vol. 3, no. 2, p. 143-148.

MARQUES, FPL. and BROOKS, DR., 2003. Taxonomic revision of Rhinebothroides (Eucestoda: Tetraphyllidea: Phyllobothriidae), parasites of neotropical freshwater stingrays (Rajiformes: Myliobatoidei: Potamotrygonidae). Journal of Parasitology, vol. 39, no. 5, p. 994-1017.

PAVANELLI, GC, MACHADO, MH, TAKEMOTO, RM, GUIDELLI, GM and LIZAMA, M de los AP. 2004. Helminth fauna of fishes: diversity and ecological aspects. In THOMAZ, SM., AGOSTINHO, AA. and HAHN, NS. (Eds.). The Upper Paraná River and its floodplain: physical aspects, ecology and conservation. The Netherlands, Leiden: Backhuys Publishers. p. 309-329.

POULIN, R., 1998. Evolutionary Ecology of Parasites. London: Chapman \& Hall. 211 p.

RANZANI-PAIVA, MJT, SILVA-SOUZA, AT, PAVANELLI, GC and TAKEMOTO, RM. 2005. Hematological characteristics and relative condiction factor $(\mathrm{Kn})$ associated with parasitism in Schizodon borellii (Osteichthyes, Anostomidae) and Prochilodus lineatus (Osteichthyes, Prochilodontidae) from Paraná River, Porto Rico region, Paraná, Brazil. Acta Scientiarum, Biological Sciences, vol. 22, no. 2, p. 515-521.

REGO, AA., 1979. Contribuição ao conhecimento dos helmintos de raias fluviais Paratrygonidae. Revista Brasileira de Biologia, vol. 39 , no. 4 , p. $879-890$. 
RÓZSA, L., REICZIGEL, J. and MAJOROS, G., 2000. Quantifying parasites in samples of hosts. Journal of Parasitology, vol. 86, no. 2, p. 228-232.

SILVA, AGC., 2006. Morfometria e ecologia de Potamotrygon motoro (Natterer in Mueller \& Henle, 1841) e Potamotrygon falkneri Castex \& Maciel, 1963 (Chondrichthyes:Potamotryg onidae) da planície de inundação do alto rio Paraná, Brasil. Maringá: Department of Biology, State University of Maringá. Master Dissertation.

SOUZA-FILHO, EE., ROCHA, PC., COMUNELlO, E. and STEVAUX, JC., 2004. Effects of the Porto Primavera Dam on physical environment of the downstream floodplain. In THOMAZ, SM., AGOSTINHO, AA. and HAHN, NS. (Eds.). The Upper Paraná River and its floodplain: physical aspects, ecology and conservation. The Netherlands, Leiden: Backhuys Publishers. p. 55-74.

TAKEMOTO, RM. and PAVANELLI, GC., 2000. Aspects of the Ecology of Proteocephalid cestodes parasites of Sorubim lima (Pimelodidae) of the upper Paraná river, Brazil: I. Structure and influence of hosts size and sex. Revista Brasileira de Biologia = Brazilian Journal of Biology, vol. 60, no. 4, p. 577-584.

TAVARES-DIAS, M., MORAES, FR., MARTINS, ML. and KRONKE, SN., 2000. Fator de condição e relação hepato e esplenossomática em teleósteos de água doce naturalmente parasitados. Acta Scientiarum. Biological Sciences, vol. 22, no. 2, p. 533-537.

TIERNEY, JF., HUNTINGFORD, FA. and CROMPTON, DWT., 1996. Body condition and reproductive status in sticklebacks exposed to a single wave of Schistocephalus solidus infection. Journal of Fish Biology, vol. 49, no. 3, p. 483-493. 
